\title{
Increased Epidermal Growth Factor Levels in Human Milk of Mothers with Extremely Premature Infants
}

\author{
BOHUSLAV DVORAK, CAMELLIA C. FITUCH, CATHERINE S. WILLIAMS, \\ NANCY M. HURST, AND RICHARD J. SCHANLER \\ Department of Pediatrics and Steele Memorial Children's Research Center [B.D., C.S.W.], and \\ Department of Cell Biology and Anatomy [B.D.], the University of Arizona, Tucson, Arizona 85724, \\ U.S.A.; and Department of Pediatrics [C.C.F., N.M.H., R.J.S], Baylor College of Medicine, \\ Houston, Texas 77030, U.S.A.
}

\begin{abstract}
Maternal milk is the major source of nutrients and growthpromoting substances in the first weeks of life for the majority of neonates. Epidermal growth factor (EGF) and transforming growth factor- $\alpha$ (TGF- $\alpha)$ are trophic peptides present in human milk with significant healing effects on injured gastrointestinal mucosa. Decreasing gestational age of neonates is associated with higher risk of developing gastrointestinal disorders, and human milk provides better protection against these diseases compared with formula. The aim of this study was to evaluate the concentrations of EGF and TGF- $\alpha$ in human milk collected from mothers with infants born: extremely preterm, preterm, and full term. Milk samples were collected at the end of first, second, and fourth week postpartum from each mother of infants born in one of the three gestational age groups: extremely preterm (23-27 $\mathrm{wk}, n=16)$, preterm $(32-36 \mathrm{wk}, n=16)$, and full term $(38-42$ wk, $n=15)$. Milk concentrations of EGF and TGF- $\alpha$ were quantified with a homologous RIA in the milk aqueous fraction. Concentrations of EGF in human milk from the extremely pre-
\end{abstract}

\section{ABSTRACT}

term group (23-27 wk) were significantly higher compared with values from the preterm and full-term groups throughout the first month of lactation. A similar pattern was observed with human milk TGF- $\alpha$; however, milk TGF- $\alpha$ levels were lower than EGF. In conclusion, we have found higher concentrations of EGF and TGF- $\alpha$ in human milk of mothers with extremely preterm babies. These data may indicate the potential importance of milk-borne EGF and TGF- $\alpha$ for the development of extremely premature infants. (Pediatr Res 54: 15-19, 2003)
Abbreviations
EGF, epidermal growth factor
EGF-R, epidermal growth factor receptor
EPT, extremely preterm
FT, full term
PT, preterm
NEC, necrotizing enterocolitis
TGF- $\alpha$, transforming growth factor- $\alpha$

Human milk is a unique and well-balanced source of nutrition for the newborn. Milk contains not only major nutrients (proteins, carbohydrates, and lipids) but also a variety of components such as minerals, vitamins, enzymes, hormones, growth factors, and immunoglobulins important for growth and healthy development during the neonatal period (1-3). As advances in neonatal care have significantly increased, the survival of extremely prematurely born neonates have increased (4). Yet these infants have the highest incidence of morbid events, such as NEC (5). Questions have arisen about

Received July 3, 2002; accepted December 11, 2002.

Correspondence: B. Dvorak, Ph.D., Department of Pediatrics, University of Arizona1501 N. Campbell Avenue, P.O. Box 245073, Tucson, AZ 85724-5073, U.S.A.; e-mail: dvorakb@peds.arizona.edu

Supported by the National Institute of Child Health and Human Development grants HD26013 and HD39657 (B.D.).

DOI: 10.1203/01.PDR.0000065729.74325.71 the most suitable and relevant nutritional support for these immature infants $(6,7)$.

Within the last three decades, a large number of biologically active peptides have been identified in human milk (8-10), and the list is continuously growing (11-13). Among these, EGF is one of the major peptide growth factors present both in colostrum and human milk (14-17). Human milk EGF levels are highest in the first days after parturition and then gradually decrease during the first 2 wk of lactation (17). Another structural homolog of EGF, TGF- $\alpha$ is also present in human colostrum and milk $(15,18)$, but at much lower concentrations than is EGF. However, neither peptide is found in commercial infant formulas.

Although the roles of milk-borne EGF and TGF- $\alpha$ on the developing neonate are not clearly understood, recent studies indicate the importance of these peptides in repair processes in injured intestinal mucosa (19). The biologic actions of EGF 
and TGF- $\alpha$ are mediated via binding to the EGF-R, and the expression of EGF-R in fetal and neonatal gut (20) suggests their role in intestinal development (21). With decreasing gestational age, critical gastrointestinal functions are compromised and extremely premature infants are at highest risk of developing gastrointestinal disorders, such as NEC. Further, the feeding of human milk to premature infants is associated with a lower incidence of gastroenteritis (22) and NEC than formula $(5,23)$.

To determine whether the concentration of growth factors in human milk varies with gestation, we evaluated the concentrations of EGF and TGF- $\alpha$ in human milk collected during the first month of lactation from mothers with EPT, PT, and FT infants. Because neonatal gastrointestinal diseases typically develop within the first postpartum weeks, milk EGF and TGF- $\alpha$ concentrations and protein content were evaluated longitudinally during the first month of lactation.

\section{METHODS}

Sample collection. Mothers of infants in the neonatal nursery at Texas Children's Hospital were recruited. Informed written agreement was obtained. The protocol was approved by the Institutional Review Board for Human Subject Research at the Baylor College of Medicine Hospital, Houston, TX, U.S.A. Human milk samples were obtained from mothers of infants born EPT (23-27 wk gestational age; $n=16)$, PT (32-36 wk gestational age; $n=16)$, and FT (38-42 wk gestational age; $n$ $=15$ ). Milk samples were collected in midmorning by a single expression from one breast and brought to the hospital unfrozen at the end of the first, second, and fourth weeks postpartum. Each mother supplied three samples, one for each time point. All samples were stored at $-70^{\circ} \mathrm{C}$ before analysis.

Milk sample preparation. Frozen milk samples were quickly thawed, mixed (1:4 by volume) with $50 \mathrm{mM}$ Tris buffer $(\mathrm{pH} 7.4)$, and centrifuged at $16,000 \times g$ at $4^{\circ} \mathrm{C}$ for $15 \mathrm{~min}$. Defatted milk whey was carefully aspirated and centrifuged again (as above). The clear milk whey volume was recorded, and samples were lyophilized and stored at $-20^{\circ} \mathrm{C}$ before RIA analysis.

Protein measurements. Milk protein concentrations were measured as described previously (24). Assays for total protein content (25) were determined by spectrophotometry (SPECTRAmax PLUS, Molecular Devices, Sunnyvale, CA, U.S.A.).

$\boldsymbol{E G F}$ and $\boldsymbol{T G F}-\boldsymbol{\alpha} \boldsymbol{R I A}$. Before RIA analysis, each sample was rehydrated with double-distilled water. Human milk EGF content was measured using human EGF RIA kit, (Biomedical Technologies, Inc, Stoughton, MA, U.S.A.) as described in the manufacturer's protocol. Milk TGF- $\alpha$ content was measured using rat TGF- $\alpha$ RIA kit (Peninsula Laboratories, Inc, Belmont, CA, U.S.A.) as described in the manufacturer's protocol. The specificity of anti-human TGF- $\alpha$ antibody guaranteed by the manufacturer is $100 \%$ cross-reactivity with human TGF- $\alpha$ and $0 \%$ cross-reactivity with human EGF. Interassay variation for both EGF and TGF- $\alpha$ was $10 \%$ or less.

Statistics. Statistical analyses were performed by ANOVA followed by Fisher's protected least significant difference using the statistical program StatView for Macintosh computers
(Abacus Concepts Inc, Berkeley, CA, U.S.A.). A value of $p<$ 0.05 was considered significant at the $95 \%$ confidence level. All data are expressed as the mean \pm SEM.

\section{RESULTS}

Protein concentrations in human milk. Milk protein concentrations were evaluated to verify that any changes in peptide growth factor concentrations were not a result of differences in total protein content. Total protein concentration in all experimental groups was highest on $\mathrm{d} 7$ of lactation and then gradually decreased during the first month of lactation (Fig. 1). There were no statistically significant differences in milk protein concentrations among experimental groups on d 7. However, on d 14 the EPT group exhibited significantly higher milk protein concentration compared with the PT and FT groups ( $p$ $<0.05)$. On d 28, statistically significant reduction in milk protein concentration was observed between the EPT and PT groups $(p<0.05)$.

Milk EGF levels. Human milk from the EPT group (23-27 wk gestational age) had significantly higher concentrations of EGF compared with values in milk from the PT and FT groups (Fig. 2). The same trend was observed when milk EGF data were expressed as the content of EGF per gram of milk protein (EPT, $7.9 \pm 0.9$; PT, $4.8 \pm 0.5 ; \mathrm{FT}, 4.9 \pm 0.5 \mu \mathrm{g} / \mathrm{g}$ protein; $p$ $<0.01)$. Milk concentrations of EGF between the PT and FT groups were not significantly different. Longitudinally, there was no statistical difference in EGF concentration from the EPT group. However, the EGF concentration from the PT and FT groups did show statistically significant decrease with time (PT d 7 versus d 28, $p<0.001$; FT d 7 versus d 28; $p<0.05$ ).

Milk TGF- $\alpha$ levels. Human milk TGF- $\alpha$ concentrations showed a similar pattern as observed for EGF values (Fig. 3), with significantly higher TGF- $\alpha$ concentrations in the EPT group compared with the PT or FT groups $(p<0.05)$. Moreover, the absolute values of milk TGF- $\alpha$ were $100-1000$ times

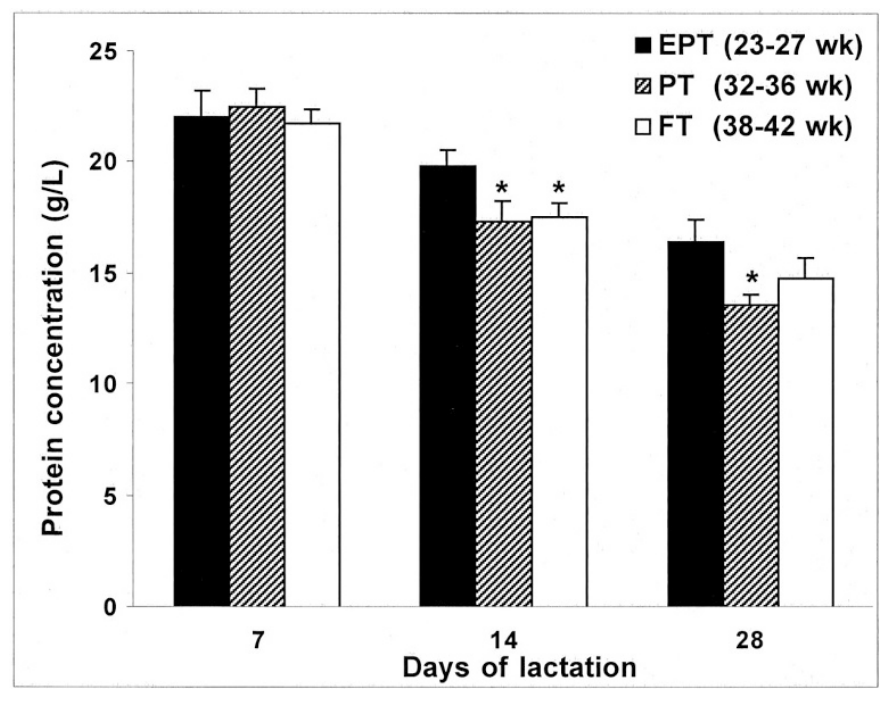

Figure 1. Total protein content in human milk from mothers of infants born EPT (23-27 wk gestational age, $n=16)$, PT (32-36 wk gestational age, $n=$ 16 ), and FT (38-42 wk gestational age, $n=15)$ during the first month of lactation. Columns are mean values, vertical lines are SEM. $* p<0.05$ EPT $v s$ PT or FT group. 


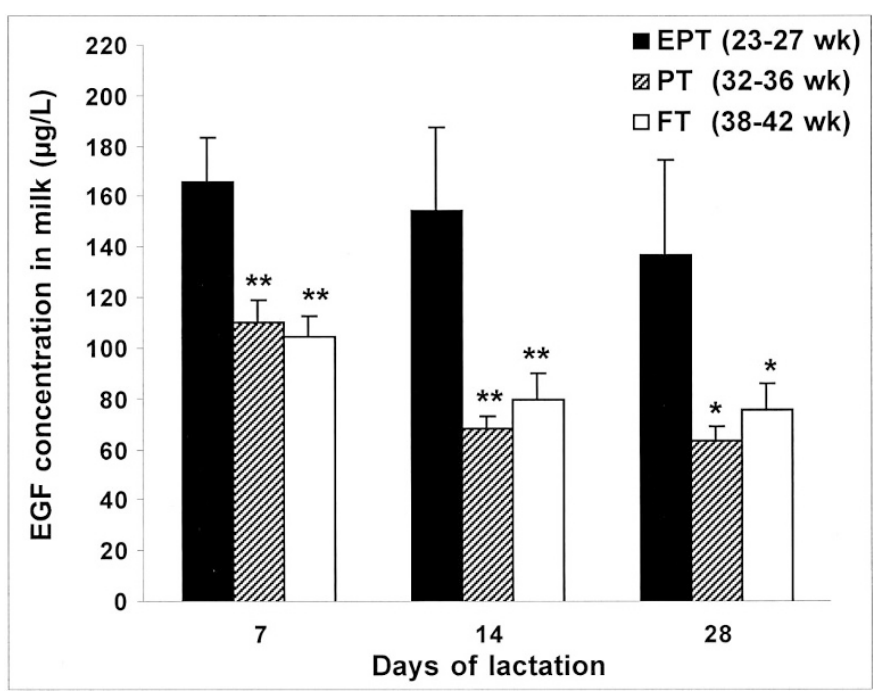

Figure 2. EGF concentrations in human milk from mothers of infants born EPT (23-27 wk gestational age, $n=16)$, PT (32-36 wk gestational age, $n=$ 16 ), and FT (38-42 wk gestational age, $n=15)$ during the first month of lactation. Milk EGF concentrations were measured using a homolog RIA. Columns are mean values, vertical lines are SEM. $* * p<0.01$ and $* p<0.05$ EPT vs PT or FT group.

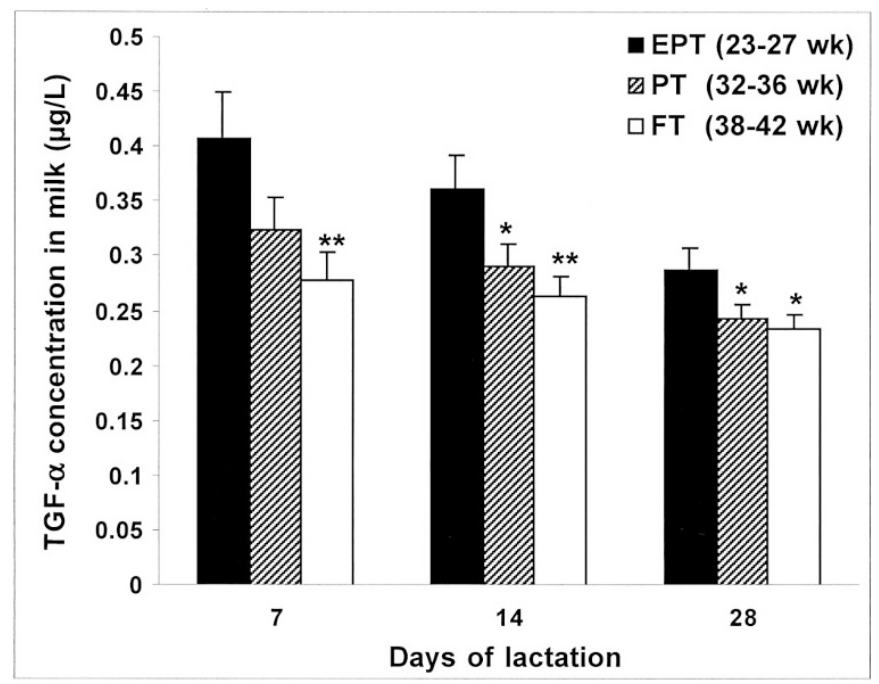

Figure 3. TGF- $\alpha$ concentrations in human milk from mothers of infants born EPT (23-27 wk gestational age, $n=16$ ), PT (32-36 wk gestational age, $n=$ 16 ), and FT (38-42 wk gestational age, $n=15)$ during the first month of lactation. Milk TGF- $\alpha$ concentrations were measured using a homolog RIA. Columns are mean values, vertical lines are SEM. $* * p<0.01$ and $* p<0.05$ EPT vs PT or FT group.

less (ranging from 0.2 to $0.6 \mu \mathrm{g} / \mathrm{L}$ ) compared with the corresponding EGF data (ranging from 40 to $560 \mu \mathrm{g} / \mathrm{L}$ ). Longitudinally, TGF- $\alpha$ concentration from the EPT and PT groups were statistically decreased between d 7 and d $28(p<0.01)$. There was no statistically significant difference in the FT group longitudinally.

\section{DISCUSSION}

The present study describes EGF and TGF- $\alpha$ levels in human milk from mothers with EPT (23-27 wk gestation) babies and compares them to the EGF and TGF- $\alpha$ levels in the milk from mothers with PT (32-36 wk) or FT (38-42 wk) babies. Human milk EGF concentrations in the EPT group were significantly higher $(60-80 \%)$ compared with the PT and FT groups. This trend was observed throughout the first month of lactation, suggesting that increased secretion of EGF into the EPT milk is a long-lasting phenomenon. A similar pattern was detected in the milk TGF- $\alpha$ levels. This is in contrast to other milk nutrients whose concentrations decrease with time of lactation (2). Milk of mothers from the EPT group had significantly higher concentrations of TGF- $\alpha$.

Results from our studies clearly indicate elevated EGF levels in human milk from mothers with EPT babies throughout the first month of lactation. Human milk EGF levels reported in previous studies have been contradictory and not clearly defined. Whereas Read et al. (17) found markedly higher EGF levels in colostrum compared with mature milk, Connolly and Rose (15) detected similar concentrations of EGF in colostrum and milk. Moran et al. (16) reported no difference in the concentration of EGF in milk from women delivering preterm versus full-term babies. However, the latter study compared preterm infants of 27 to $32 \mathrm{wk}$ of gestation. In our study significant differences in milk EGF levels were detected in EPT babies (23-27 week gestation) only. Read et al. (26) reported elevated EGF levels in colostrum and human milk of mothers with very premature babies compared with less premature or term babies. However, they used a radioreceptor technique, which is based on a competitive binding of ligands to the EGF-R. This method simultaneously detects several members of the EGF-like peptide family, such as EGF, TGF- $\alpha$, heparinbinding EGF, and betacellulin, all reported to be found in milk $(12,14,18,27)$. In the present study, we used a peptidespecific and quantitative RIA, with no cross-reactivity among members of the EGF-like family of peptides. In addition, the milk samples were divided into three experimental groups based on the gestational age of the newborns, and the results were consistent during the three periods.

The presence of TGF- $\alpha$ in colostrum and human milk is even less understood than EGF. Originally, TGF- $\alpha$-like activity was detected in human colostrum; however, the exact concentration was not described (28). Later, Connolly and Rose (15) detected the presence of TGF- $\alpha$ in human milk using a radioreceptor technique. Okada et al. (18) verified TGF- $\alpha$ concentration in human milk using a specific RIA assay. Wagner et al. (29) have found that human milk contains different biochemical forms of TGF- $\alpha$ that can originate from human milk macrophage secretion. Results from these studies have shown that TGF- $\alpha$ concentration in mature milk is markedly lower compared with EGF levels. To our knowledge, this is the first report of TGF- $\alpha$ levels in the milk of mothers with extremely prematurely born babies. In the present study, TGF- $\alpha$ levels were evaluated in human milk samples at different gestational ages and lactation times. Similar to EGF, TGF- $\alpha$ levels were the highest in the EPT group compared with PT and FT groups. Although statistically significant, the differences in TGF- $\alpha$ levels in milk from three gestational age groups were less pronounced compared with the differences in EGF levels from the same experimental groups. However, TGF- $\alpha$ levels were measured in the aqueous portion of human 
milk only. Recent studies indicate that TGF- $\alpha$ activity can also be detected in the fat portion of human milk (30). Therefore, milk fat globules can perhaps serve as an additional source of milk TGF- $\alpha$ (31).

What is the physiologic relevance of these results? Britton et al. (32) have shown that EGF is resistant to degradation by gastric juices of human premature infants. The presence of EGF-R in fetal and neonatal gut is well established (20), and developing intestine is considered to be a target organ for milk-borne EGF and TGF- $\alpha(19,33)$. With decreasing gestational age of newborns, the critical functions of the gastrointestinal tract are compromised, and neonates are at high risk of developing intestinal disorders. A typical example is neonatal NEC, in which 90 to $95 \%$ of the cases occur in prematurely born infants $(34,35)$. A multicenter study from the United Kingdom has shown that the incidence of NEC among premature babies fed human milk is 6-10 times lower compared with formula-fed babies (5). However, the component(s) of human milk associated with these protective effects were not identified. Amniotic fluid contains significant concentrations of EGF that gradually increase during pregnancy, with the highest level achieved at the end of the normal gestation period (36). In contrast to human milk, EGF is absent in commercially available infant formulas $(37,38)$. Clinical studies have shown reduced serum and salivary EGF levels in neonates with NEC when compared with healthy babies $(39,40)$. In an animal model of NEC, we have recently shown that milk-borne EGF reduces the incidence and severity of NEC-like injury in neonatal rats (41). In suckling animals, supplementation of EGF into formula enhances the growth of stomach and the small intestine (42), induces precocious maturation of intestinal brush-border disaccharidase activities (43), and modulates intestinal nutrient transport (44). Based on these clinical and experimental studies, we speculate that elevated levels of EGF in human milk of extremely prematurely born babies can be potentially responsible for the protective effect of maternal milk against neonatal diseases.

\section{CONCLUSIONS}

In the present study we have shown that human milk EGF and TGF- $\alpha$ concentrations are markedly higher in mothers with EPT babies, compared with those with PT or FT babies. Because EPT infants are often maintained for extended periods on total parenteral nutrition and enteral formula is devoid of peptide growth factors, a better understanding of the physiologic functions of milk-borne growth factors on the development of neonates is critical for future clinical use of these growth factors.

\section{REFERENCES}

1. Goldman AS 2000 Modulation of the gastrointestinal tract of infants by human milk: interfaces and interactions - an evolutionary perspective. J Nutr 130:426S-431S

2. Jensen RG 1995 Handbook of Milk Composition. Academic Press, San Diego, pp 1-919

3. Lonnerdal B 2000 Breast milk: a truly functional food. Nutrition 16:509-511

4. Lemons JA, Bauer CR, Oh W, Korones SB, Papile LA, Stoll BJ, Verter J, Temprosa M, Wright LL, Ehrenkranz RA, Fanaroff AA, Stark A, Carlo W, Tyson JE, Donovan EF, Shankaran S, Stevenson DK 2001 Very low birth weight outcomes of the National Institute of Child Health and Human Development Neonatal Research
Network. January 1995 through December 1996. NICHD Neonatal Research Network, Pediatrics 107:E1

5. Lucas A, Cole TJ 1990 Breast milk and neonatal necrotising enterocolitis. Lancet 336:1519-1523

6. Schanler RJ 2001 The use of human milk for premature infants. Pediatr Clin North Am 48:207-219

7. Schanler RJ, Shulman RJ, Lau C 1999 Feeding strategies for premature infants: beneficial outcomes of feeding fortified human milk versus preterm formula. Pediatrics 103:1150-1157

8. Donnet-Hughes A, Duc N, Serrant P, Vidal K, Schiffrin EJ 2000 Bioactive molecules in milk and their role in health and disease: the role of transforming growth factor-beta. Immunol Cell Biol 78:74-79

9. Koldovsky O 1989 Search for role of milk-borne biologically active peptides for the suckling. J Nutr 119:1543-1551

10. Walker WA 1997 Breast milk and the prevention of neonatal and preterm gastrointestinal disease states: a new perspective. Chung Hua Min Kuo Hsiao Erh K'o I Hsueh Hui Tsa Chi [Acta Paediatr Sin] 38:321-331

11. Bianco C, Wechselberger C, Ebert A, Khan NI, Sun Y, Salomon DS 2001 Identification of cripto-1 in human milk Breast Cancer Res Treat 66:1-7

12. Michalsky MP, Lara-Marquez M, Chun L, Besner GE 2002 Heparin-binding EGFlike growth factor is present in human amniotic fluid and breast milk J Pediatr Surg $37: 1-6$

13. Takahata Y, Takada H, Nomura A, Ohshima K, Nakayama H, Tsuda T, Nakano H, Hara T 2001 Interleukin-18 in human milk Pediatr Res 50:268-272

14. Carpenter G 1980 Epidermal growth factor is a major growth-promoting agent in human milk. Science 210:198-199

15. Connolly JM, Rose DP 1988 Epidermal growth factor-like proteins in breast fluid and human milk. Life Sci 42:1751-1756

16. Moran JR, Courtney ME, Orth DN, Vaughan R, Coy S, Mount CD, Sherrell BJ, Greene HL 1983 Epidermal growth factor in human milk: daily production and diurnal variation during early lactation in mothers delivering at term and at premature gestation. J Pediatr 103:402-405

17. Read LC, Upton FM, Francis GL, Wallace JC, Dahlenberg GW, Ballard FJ 1984 Changes in the growth-promoting activity of human milk during lactation. Pediatr Res 18:133-139

18. Okada M, Ohmura E, Kamiya Y, Murakami H, Onoda N, Iwashita M, Wakai K, Tsushima T, Shizume K 1991 Transforming growth factor (TGF)-alpha in human milk. Life Sci 48:1151-1156

19. Playford RJ, Macdonald CE, Johnson WS 2000 Colostrum and milk-derived peptide growth factors for the treatment of gastrointestinal disorders. Am J Clin Nutr 72:5-14

20. Chailler P, Menard D 1999 Ontogeny of EGF receptors in the human gut. Front Biosci 4:D87-D101

21. Playford RJ, Wright NA 1996 Why is epidermal growth factor present in the gut lumen? Gut 38:303-305

22. Jasso Gutierrez L, Olivos Fernandez V 1980 El calostro humano en la prevencion de la diarrea y de la enterocolitis necrosante. Bol Med Hosp Infant Mex 37:23-30

23. Howie PW, Forsyth JS, Ogston SA, Clark A, Florey CD 1990 Protective effect of breast feeding against infection. BMJ 300:11-16

24. Dvorak B, Koldovsky O 1994 The presence of transforming growth factor-alpha in the suckling rat small intestine and pancreas and the absence in rat milk. Pediatr Res 35:348-353

25. Lowry OH, Rosebgrough NJ, Farr AL, Randal RJ 1951 Protein measurement with the folin phenol reagent. J Biol Chem 193:265-275

26. Read LC, Francis GL, Wallace JC, Ballard FJ 1985 Growth factor concentrations and growth-promoting activity in human milk following premature birth. J Dev Physiol 7:135-145

27. Dunbar AJ, Priebe IK, Belford DA, Goddard C 1999 Identification of betacellulin as a major peptide growth factor in milk: purification, characterization and molecular cloning of bovine betacellulin. Biochem J 344:713-721

28. Noda K, Umeda M, Ono T 1984 Transforming growth factor activity in human colostrum. Gann 75:109-112

29. Wagner CL, Forsythe DW, Pittard WB 1995 Variation in the biochemical forms of transforming growth factor-alpha present in human milk and secreted by human milk macrophages. Biol Neonate 68:325-333

30. McPherson RJ, Wagner CL 2001 The effect of pasteurization on transforming growth factor alpha and transforming growth factor beta 2 concentrations in human milk. Adv Exp Med Biol 501:559-566

31. Wagner CL 2002 Amniotic fluid and human milk: a continuum of effect? J Pediatr Gastroenterol Nutr 34:513-514

32. Britton JR, George-Nascimento C, Udall JN, Koldovsky O 1989 Minimal hydrolysis of epidermal growth factor by gastric fluid of preterm infants. Gut 30:327-332

33. Ichiba H, Kusuda S, Itagane Y, Fujita K, Issiki G 1992 Measurement of growth promoting activity in human milk using a fetal small intestinal cell line. Biol Neonate $61: 47-53$

34. Kliegman RM 1999 Neonatal Necrotizing Enterocolitis. WB Saunders, Philadelphia, pp 445-465

35. Neu J 1996 Necrotizing enterocolitis: the search for a unifying pathogenic theory leading to prevention. Pediatr Clin North Am 43:409-432

36. Hofmann GE, Abramowicz JS 1990 Epidermal growth factor (EGF) concentrations in amniotic fluid and maternal urine during pregnancy. Acta Obstet Gynecol Scand 69:217-221

37. Iacopetta BJ, Grieu F, Horisberger M, Sunahara GI 1992 Epidermal growth factor in human and bovine milk. Acta Paediatr 81:287-291

38. Yagi H, Suzuki S, Noji T, Nagashima K, Kuroume T 1986 Epidermal growth factor in cow's milk and milk formulas. Acta Paediatr Scand 75:233-235 
39. Helmrath MA, Shin CE, Fox JW, Erwin CR, Warner BW 1998 Epidermal growth factor in saliva and serum of infants with necrotising enterocolitis. Lancet 351:266-267

40. Shin CE, Falcone Jr RA, Stuart L, Erwin CR, Warner BW 2000 Diminished epidermal growth factor levels in infants with necrotizing enterocolitis. J Pediatr Surg 35:173-176

41. Dvorak B, Halpern MD, Holubec H, Williams CS, McWilliam DL, Dominguez JA, Stepankova R, Payne CM, McCuskey RS 2002 Epidermal growth factor reduces the development of necrotizing enterocolitis in a neonatal rat model. Am J Physiol Gastrointest Liver Physiol 282:G156-G164
42. Berseth CL 1987 Enhancement of intestinal growth in neonatal rats by epidermal growth factor in milk. Am J Physiol Gastrointest Liver Physiol 253:G662G665

43. O'Loughlin EV, Chung M, Hollenberg M, Hayden J, Zahavi I, Gall DG 1985 Effect of epidermal growth factor on ontogeny of the gastrointestinal tract. Am J Physiol Gastrointest Liver Physiol 249:G674-G678

44. Opleta-Madsen K, Meddings JB, Gall DG 1991 Epidermal growth factor and postnatal development of intestinal transport and membrane structure. Pediatr Res $30: 342-350$ 